\title{
Sympatric Clupeoid Fish Larvae in the Northeastern Mediterranean: Coexistence or Avoidance?
}

\author{
Athanassios C. Tsikliras \\ Laboratory of Ichthyology, School of Biology, Aristotle University of Thessaloniki, P.O. Box 134, 54124 Thessaloniki, Greece \\ Correspondence should be addressed to Athanassios C. Tsikliras; atsik@bio.auth.gr
}

Received 3 August 2014; Revised 14 October 2014; Accepted 15 October 2014; Published 10 November 2014

Academic Editor: Sveinn Are Hanssen

Copyright (C) 2014 Athanassios C. Tsikliras. This is an open access article distributed under the Creative Commons Attribution License, which permits unrestricted use, distribution, and reproduction in any medium, provided the original work is properly cited.

\begin{abstract}
The summer (July 2002 and 2003) larval concentrations of two commercially important clupeoid species (order: Clupeiformes), the European anchovy (Engraulis encrasicolus) and round sardinella (Sardinella aurita), were measured in Kavala Gulf (northern Aegean Sea), in order to examine their distribution patterns. Anchovy was generally most abundant, reaching 13852 larvae $10 \mathrm{~m}^{-2}$ in 2003 and occurred in more stations compared to round sardinella. Despite the spawning of both species occurring across the entire gulf, the general spatial distribution of their larvae was different, with European anchovy larvae occupying the entire gulf and round sardinella larvae mainly concentrated at offshore stations. The reason proposed for the spatial segregation of their larvae is direct competition for resources. Yet, coexistence of the two species was observed in frontal areas with abundant food resources that prevent competition.
\end{abstract}

\section{Introduction}

Competition can be an important factor in structuring ichthyofaunal communities because it largely determines the distribution and resource partitioning of closely related species, hence affecting their population characteristics [1]. Sympatric occurrence of closely related species utilizing the same resources may result in interspecific competition [2], which in turn may lead to one species differentiating in order to survive [3]. This condition holds only when the shared resource is limited [4]. On the contrary, competing species can coexist when a resource is unlimited [5] or above the surviving level of an organism [6].

Competition among fish larval stages may be avoided through successive larval appearance in time emerging from successive adult spawning [7, 8], spatial segregation [9], or occupation of different depth ranges [10]. Temporal succession of spawning among closely related species with common life-history characteristics, as a strategy for avoiding resource overlapping, has been reported to occur within families of marine fishes (Sparidae [11]; Mugilidae [12]). Competition avoidance through the selection of distinct habitats (in terms of depth range and distance from shore) will ensure optimal growth and survival at the vulnerable larval stages [1]. Such selective adaptations to habitats with often less favourable conditions have been reported for clupeoid fishes (order: Clupeiformes) at various life stages [13].

Clupeoid fishes consist of one of the major fish groups that account for more than $30 \%$ of the global marine landings [14]. In Greek waters, three clupeoid fishes, the European anchovy (Engraulis encrasicolus, family: Engraulidae), the European sardine (Sardina pilchardus, family: Clupeidae), and round sardinella (Sardinella aurita, family: Clupeidae), constitute the vast majority of pelagic fish landings reaching $40 \%$ of the total marine captured production [15]. These clupeoid species are sympatric [9] and omnivorous with preference for zooplankton [16] and have common lifehistory characteristics (fast growing, small sized, short lived, early maturing, highly fecund with pelagic eggs and larvae [17]). In the Mediterranean Sea, the European sardine spawns during the cold season (autumn-winter: $[7,8]$ ), while the European anchovy is a spring-summer spawner $[8,18]$. Contrary to the European sardine and anchovy that exhibit prolonged spawning, round sardinella at the NE Mediterranean spawns over a relatively short period during the summer [19]. The consecutive, nonoverlapping spawning of 


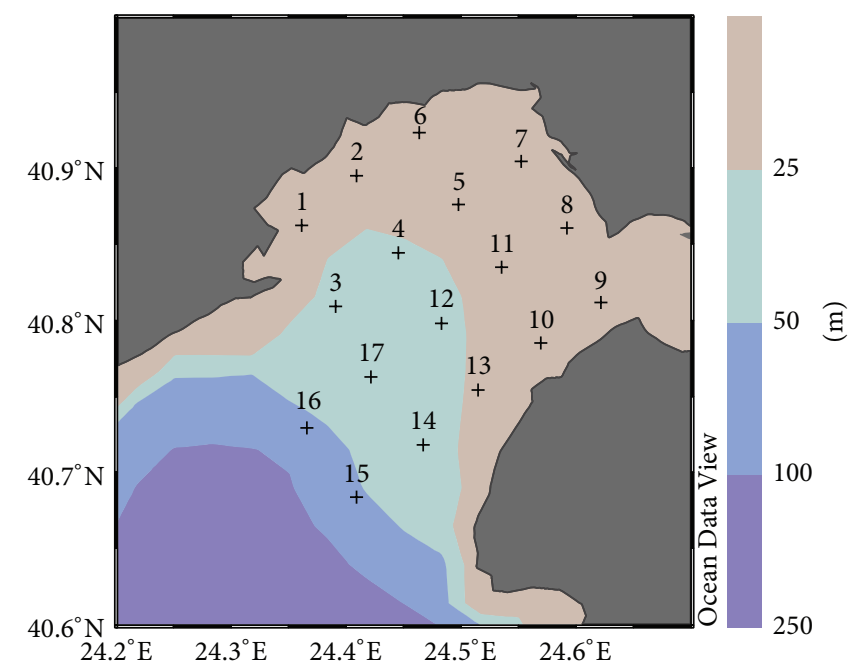

FIGURE 1: Map of the study area (Kavala Gulf, northern Aegean Sea, Greece) showing the grid of 17 sampling stations (+). The depth contours of 25, 50 and $100 \mathrm{~m}$ are indicated.

sardine and anchovy eliminates the possibility of interspecific competition between their larval stages. However, the recent geographic shift and subsequent population outburst of round sardinella in the northern Aegean Sea [20] and the partial coincidence of its spawning with the peak of anchovy spawning that occurs in late June-early July [8] may generate competition among their offspring for resources. Previous work on the ichthyoplankton assemblages of the northern Aegean Sea during the summer confirms the cooccurrence of round sardinella and anchovy larvae at certain areas [21].

Thus, the principal objective of this work is to examine any coexisting/avoiding patterns between anchovy and round sardinella larvae through the assessment of their spatial distribution and abundance and secondly to investigate whether these patterns are determined by physical (e.g., temperature) or biological (e.g., competition) processes. The findings of the present work may be applicable to other areas of the northern Mediterranean coastline where round sardinella has been recently expanded (e.g., Adriatic Sea) and may compete with anchovy and sardine for food and space.

\section{Materials and Methods}

Clupeid larval fish and hydrographic data were collected at the northern Aegean Sea (Kavala Gulf, $24^{\circ} 25^{\prime} \mathrm{E}, 40^{\circ} 52^{\prime} \mathrm{N}$ ) across a fixed grid of 17 stations (Figure 1) in two surveys, carried out on the 2nd and 3rd of July 2002 and 2003. Kavala Gulf is a shallow gulf covering an area of $264 \mathrm{~km}^{2}$ and is located on the continental shelf of the northern Aegean Sea (for a full description of the gulf see Tsikliras et al. [22]), which supports some of the most productive fisheries, in terms of biomass landed, in Greek waters (Greek fishing subarea $14[23])$.

A paired bongo net sampler was used for the collection of larvae. This sampler design has two $60 \mathrm{~cm}$ diameter frames fitted with $250 \mu \mathrm{m}$ mesh conical nets. A flowmeter was centrally mounted at the opening of each frame to estimate the volume of water $\left(\mathrm{m}^{3}\right)$ flowing through the net. Sampler was deployed in a double oblique tow from the surface to $1-2 \mathrm{~m}$ of the seabed. Retrieval speed was $20 \mathrm{~m} \mathrm{~min}^{-1}$. Upon recovery of the sampler, the plankton was fixed with $4 \%$ buffered formaldehyde solution for later quantitative sorting. Anchovy and round sardinella larvae were sorted and measured for standard length (SL, mm). The standard length frequency distributions of both species between "shallow" or inshore (depth not exceeding $20 \mathrm{~m}$ : stations 6, 7, 8, 9, 10, 11, 12, and 13) and "deep" or offshore (deeper than $20 \mathrm{~m}$ : stations 1, $2,3,4,5,14,15,16$, and 17) stations [24] were compared for statistical differences using the Kolmogorov-Smirnov (KS) nonparametric test.

The percent frequency of occurrence and abundance of larvae across stations were determined per survey. Clupeoid larval abundance was expressed as number of larvae beneath a unit sea surface area $\left(10 \mathrm{~m}^{2}\right)$ by dividing the numbers per sample by the volume of water filtered and then by multiplying the larvae $\mathrm{m}^{-3}$ by the sampling depth (in $\mathrm{m}$ ) during deployment [25]. Physical variables were obtained at each sampling station from CTD sensors (Ocean 301, Idronaut) deployed simultaneously with the net sampler and included temperature (SST, $\left.{ }^{\circ} \mathrm{C}\right)$, salinity (SSS), and dissolved oxygen $\left(\mathrm{SSDO}, \mathrm{mg} \mathrm{L}^{-1}\right)$. Station depth $(D, \mathrm{~m})$ was also recorded. Larval abundance and physical/station variable data were combined for both surveys in order to identify the preferences of the early stages of anchovy and round sardinella.

Schoener's niche overlap index $(N)$ was used to estimate overlap in terms of abundance between anchovy and round sardinella at each station [26]:

$$
N=1-0.5 \sum_{i=1}^{n}\left|P_{x i}-P_{y i}\right|,
$$

where $P_{x i}$ and $P_{y i}$ are ratios in terms of numbers at each station $i$ between anchovy $(x)$ and round sardinella $(y)$. The value of $N$ ranges between 0 (no overlap) and 1 (complete overlap) with $N$ values greater than 0.6 indicating important overlap [26].

Anchovy and round sardinella abundance data from each tow were transformed to $\log ($ number +1$)$ to conform to normality and homogeneity of variances. Significant differences in environmental variables and abundance of clupeoid larvae among stations and between surveys were detected using analysis of variance (ANOVA) with factors depth, divided into five depth zones $(20,30,35,40$, and $45 \mathrm{~m})$, and year $(2002,2003)$. The division to five depth zones was used only for comparing larval abundances among stations and not for comparing larval length distributions. Fisher's least significance difference (LSD) multiple range test was used to detect where the differences occurred.

To complement ANOVA, a quotient-rule analysis was applied to assess the preferred ranges of physical and station variables for anchovy and round sardinella larvae. Each variable was divided into a number of classes in a way to ensure that the maximum occurrence of measurements per class did not exceed $20 \%$ of all measurements [27]. For 

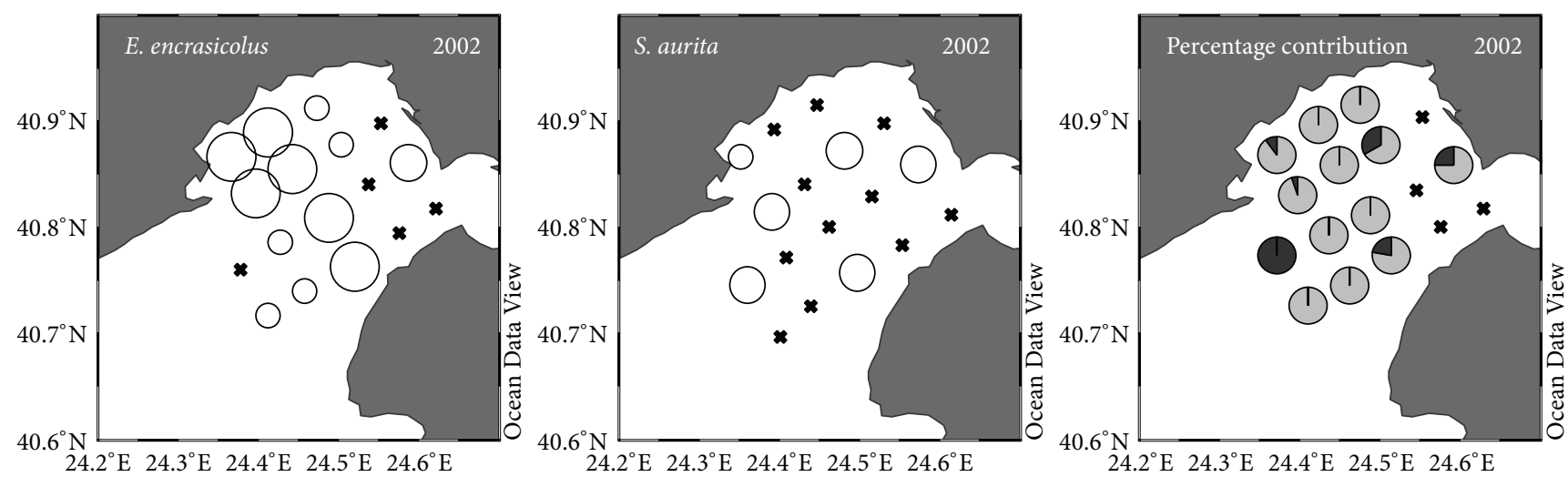

(a)
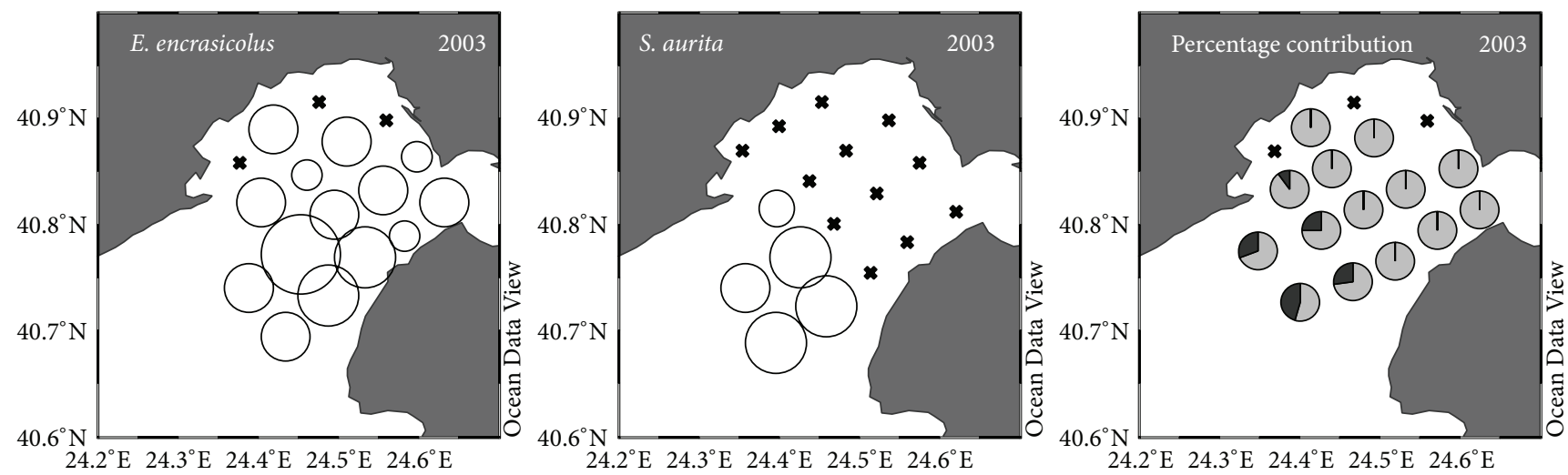

(b)

FIGURE 2: Horizontal distribution map of the number of larvae $\left(N / 10 \mathrm{~m}^{2}\right)$ for anchovy, Engraulis encrasicolus (gray) and round sardinella, Sardinella aurita (black), and their percentage contribution to the total clupeoid larvae in each station for 2002 (a) and 2003 (b) in Kavala Gulf (northern Aegean Sea, Greece). (Bubbles are proportional to abundance with smallest bubble representing 1-100 larvae $10 \mathrm{~m}^{-2}$ and largest representing $10 \times 10^{3}-15 \times 10^{3}$ larvae $10 \mathrm{~m}^{-2} ; \times$ indicates negative stations).

each species, the number of larvae found in each class was expressed as a percentage of the total number of larvae recorded (\% larvae) and was divided by the percentage frequency of occurrence of each class (\% variable) giving the quotient values $(Q)$ for each variable class [27]:

$$
Q=\frac{\% \text { larvae }}{\% \text { variable }} \text {. }
$$

Quotient values $>1$ indicate preference to a specific range of variable, while those $<1$ indicate avoidance of the specific class [27]. Quotient curves were generated from smoothed (using a 6-point running mean) quotient values and were plotted against variables.

A nonparametric Kolmogorov-Smirnov test was used to compare cumulative frequency distributions of larvae per environmental variable class against the distribution curves of that variable [27] in order to test whether the larval distribution was random with respect to physical and station variables. The same test was also used to compare the cumulative frequency distributions of anchovy and round sardinella larvae per category for each variable. In all statistical analyses a significance level of $P<0.05$ was used. All maps were produced using Ocean Data View software [28].

\section{Results}

Anchovy larvae were most abundant than round sardinella in both surveys. The frequency of occurrence of anchovy larvae across stations was high as they were collected at 12 (70\% of total) and 15 (88\% of total) stations in 2002 and 2003, respectively (Figure 2). The highest anchovy larval densities were recorded at station $3\left(414510 \mathrm{~m}^{-2}\right)$ in 2002 and at station 17 (13 $\left.85210 \mathrm{~m}^{-2}\right)$ in 2003. Round sardinella larvae were collected at 6 (35\% of total) and 5 (29\% of total) stations in 2002 and 2003, respectively, and reached $461710 \mathrm{~m}^{-2}$ in 2003 (at station 17). Smaller round sardinella larvae were collected at inshore stations, while larger larvae were collected further offshore (KS $=1.372, \mathrm{DN}=0.538, P=0.046$ : Figure 3$)$. In contrast, the length frequency distribution of anchovy larvae was homogeneous among stations $(\mathrm{KS}=0.577, \mathrm{DN}=0.333$, $P=0.892$; Figure 3).

Schoener's niche overlap index showed that the overlap between anchovy and round sardinella was lower than 0.5 in inshore stations for both surveys (2002: $N=0.488,2003$ : $N=0.349)$ and in offshore stations in $2002(N=0.341)$. Higher overlap was recorded only in offshore stations in 2003 $(N=0.639)$. When all stations were combined together, 
TABLE 1: Results of the Kolmogorov-Smirnov analysis of round sardinella, Sardinella aurita, and European anchovy, Engraulis encrasicolus, larvae (log number + 1) with physical (temperature, SST, ${ }^{\circ} \mathrm{C}$; salinity, SSS; dissolved oxygen, $\mathrm{SSDO}_{\mathrm{mg} \mathrm{L}}^{-1}$ ) and station (depth, $D$, m) variables. (DN: maximum distance between the cumulative distributions of the two samples, KS: two-sided Kolmogorov-Smirnov statistic, $P$ : level of significance, and $n$ : sample size).

\begin{tabular}{|c|c|c|c|c|c|c|c|c|c|}
\hline \multirow{2}{*}{ Variable } & \multirow{2}{*}{$n$} & \multicolumn{4}{|c|}{ Anchovy larvae } & \multicolumn{4}{|c|}{ Round sardinella larvae } \\
\hline & & Preferred range & DN & KS & $P$ & Preferred range & $\mathrm{DN}$ & KS & $P$ \\
\hline $\operatorname{SST}\left({ }^{\circ} \mathrm{C}\right)$ & 21 & $<24.4,>25.4$ & 0.200 & 0.632 & 0.818 & $>24.3$ & 0.250 & 0.790 & 0.559 \\
\hline SSS & 21 & $<32.5$ & 0.263 & 0.811 & 0.541 & $<32.5$ & 0.421 & 1.297 & 0.068 \\
\hline $\operatorname{SSDO}\left(\mathrm{mg} \mathrm{L}^{-1}\right)$ & 21 & $7.85-8.30$ & 0.217 & 0.737 & 0.648 & $7.90-8.65$ & 0.260 & 0.884 & 0.419 \\
\hline$D(\mathrm{~m})$ & 24 & $>34$ & 0.409 & 1.356 & 0.050 & $>42$ & 0.545 & 1.809 & 0.002 \\
\hline
\end{tabular}

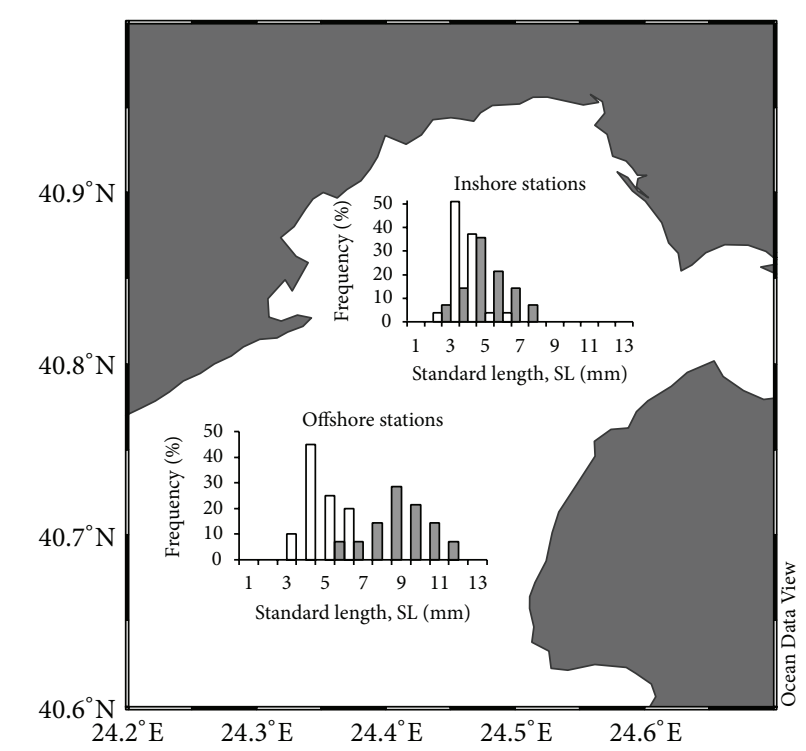

FIgURE 3: Standard length (SL, mm) frequency distributions of anchovy, Engraulis encrasicolus (white bars; $n=71$ ), and round sardinella, Sardinella aurita (grey bars; $n=25$ ) larvae in inshore and offshore stations of Kavala Gulf (northern Aegean Sea, Greece). Data from both surveys (2002 and 2003) are combined.

overlap values were lower than 0.6 (2002: $N=0.401,2003$ : $N=0.564)$, indicating no significant overlap.

The analysis of variance showed that both anchovy and round sardinella larval abundances were higher in 2003 than in 2002 (anchovy: ANOVA, $F=8.87, n=26, P=0.006$; round sardinella: ANOVA, $F=17.33, n=11, P=0.002)$. The larval densities of anchovy were strongly homogeneous among positive (i.e., excluding stations with no larvae) stations (ANOVA, $F=0.33, n=26, P=0.974$ ) and depth zones (ANOVA, $F=0.38, n=26, P=0.817$ ). Similarly, those of round sardinella were fairly homogeneous among positive stations (ANOVA, $F=4.06, n=11, P=0.212$ ) and depth zones (ANOVA, $F=0.64, n=11, P=0.611$ ).

Sea surface temperature was lower at inshore stations, with the warmest water, over $25^{\circ} \mathrm{C}$, occurring in the offshore stations located at the SW part of the gulf (Figure 4). In 2003, sea surface salinity was higher at the deeper SW part of the gulf and lower towards the shore (Figure 4).

The quotient curve plots for anchovy and round sardinella larval distributions showed their preferred range of
SST, SSS, SSDO, and depth (Table 1, Figures 4 and 5). The quotient values $>1$ for round sardinella were associated with temperatures exceeding $24.3^{\circ} \mathrm{C}$ and those of anchovy with temperatures below $24.4^{\circ} \mathrm{C}$. Round sardinella larvae tended to occur in warmer waters than anchovy ones. The preferred salinity range is identical for both species as their larvae were most abundant in salinities lower than 32.5. It seems that these species share oxygen preferences with round sardinella larvae being able to tolerate slightly broader oxygen range (7.90-8.65) than anchovy larvae (7.85-8.30). A substantial difference exists between the preferred depth ranges of the species with round sardinella larvae preferring deeper waters than anchovy larvae (Table 1, Figure 5). However, the Kolmogorov-Smirnov test showed that the distribution of anchovy larvae was random with respect to SST, SSS, and SSDO (Table 1: $P>0.54$ in all cases) and marginally random with respect to depth $(P=0.050)$. Similarly, the results from the same test (Table 1) indicated that round sardinella larvae were not randomly distributed with respect to depth $(P=$ $0.002)$ and randomly distributed with respect to SST, SSS, and SSDO $(P>0.068$ in all cases).

\section{Discussion}

Ecological theory predicts that an organism, which reduces the available resource below the surviving level of its competitors, will exclude them [6] or else competition will cause niche diversification [2]. In order to avoid competitive exclusion, when several clupeoid species spawn in the same area, the parental stocks seem to have adjusted to successive spawning, thus eliminating resource partitioning that would emerge from the cooccurrence of their larvae [10]. Similarly, in order to maximise resource utilization, clupeid larvae may segregate and occupy a wide range of different depths [10]. In any case, and irrespective of the driving force, the coincidence of anchovy and round sardinella larvae in space would increase competition when resources are limited and hence the chances of mortality or stress are increased. When conditions are favourable for larval growth and survival, the two species may coexist with minimum competition.

Despite the fact that adult anchovy and round sardinella occur and spawn across the entire Kavala Gulf [22], anchovy larvae were dominant in occurrence and abundance over round sardinella during both surveys. Their extended distribution that covered almost the entire sampling area and their exclusive occupation of the shallower N-NE part 

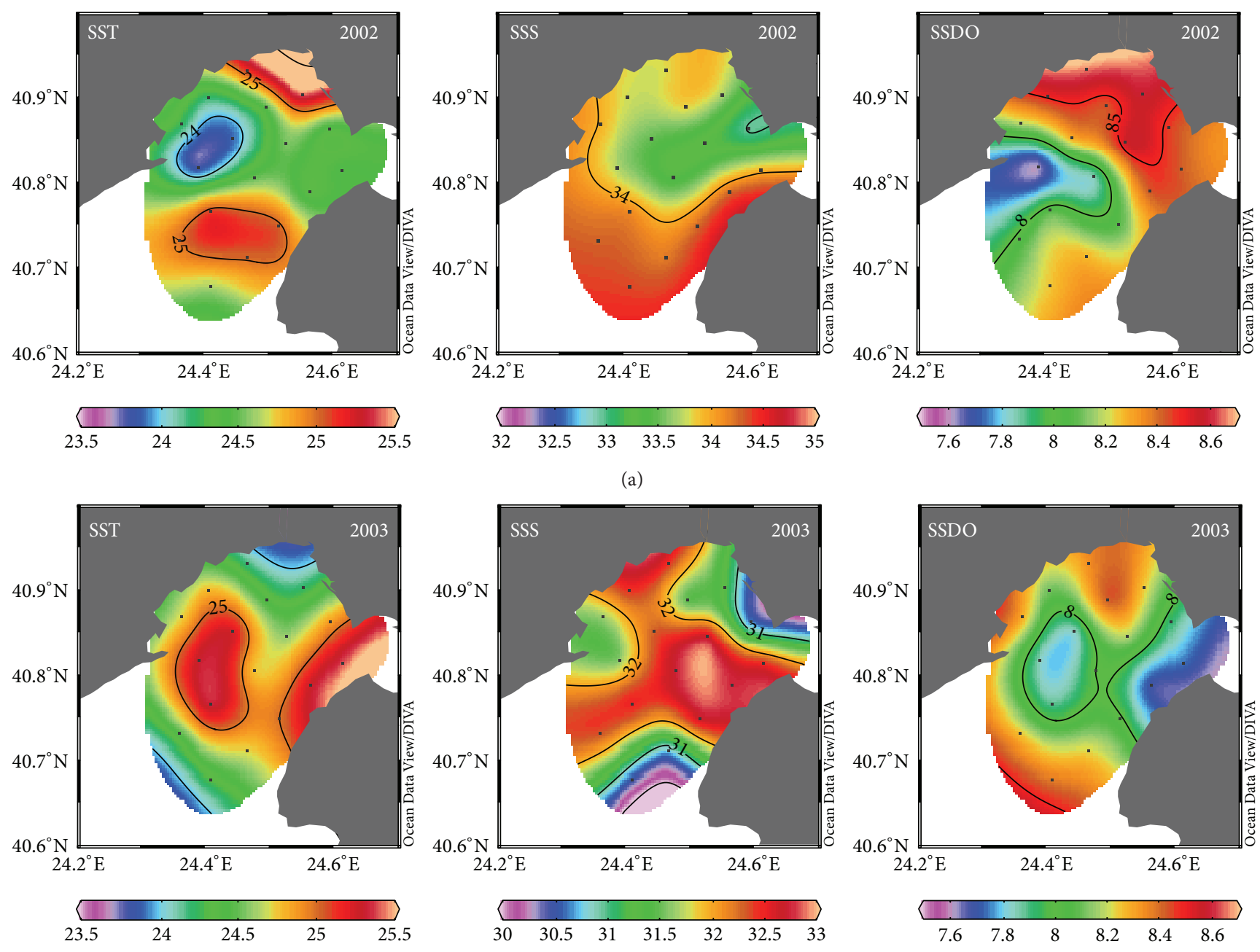

(b)

FIGURE 4: Horizontal distribution map of sea surface temperature (SST, $\left.{ }^{\circ} \mathrm{C}\right)$, sea surface salinity (SSS), and sea surface dissolved oxygen (SSDO, mg L ${ }^{-1}$ ) in early July 2002 (a) and 2003 (b) in Kavala Gulf (northern Aegean Sea, Greece).

of the gulf may be attributed to the onset of anchovy's spawning 1-2 months earlier than round sardinella's. Indeed, in the northern Aegean Sea, the spawning of anchovy occurs from April to September and peaks in late June $[8,29$, 30], while that of round sardinella occurs from May to July, generally peaks in June, but may exhibit interannual variations depending on sea temperature [19]. Additionally, the adult and larval concentrations of the multiple spawning anchovy often exceed by an order of magnitude those of round sardinella [22]. The earlier onset of anchovy's spawning and the high abundance of their larvae offer a competitive advantage against the subsequently hatched round sardinella competitors, which allows the prompt occupation of the most favourable areas. Anchovy larvae have been reported to occupy coastal areas often in areas influenced by river plumes [31], which, contrary to offshore areas, may offer higher growth rates because of higher prey availability and higher survival because of decreased predation pressure [32].
The outnumbered round sardinella larvae are consequently concentrated at stations where competition is minimized because of higher food availability [9, 33]. This behaviour is characteristic for round sardinella, a typically opportunistic and easy to adapt species [13]. Similar results, with the less abundant round sardinella larvae occupying the less favourable survival areas as a result of their possible competition with anchovy, have been reported by Palomera and Sabatés [9] for the NW Mediterranean coast. Morote et al. [33] also report larger round sardinella larvae at offshore stations possibly indicating larval transport. The same authors, however, report that round sardinella is a voracious feeder and predict that, in cases of low prey availability, and round sardinella can be more successful than anchovy [33]. In contrast, Sabatés et al. [7] report that round sardinella larvae may be disadvantageous compared to anchovy ones because their bathymetric distribution is limited to the upper $50 \mathrm{~m}$ of the water column. Thus, round sardinella larvae do not feed 


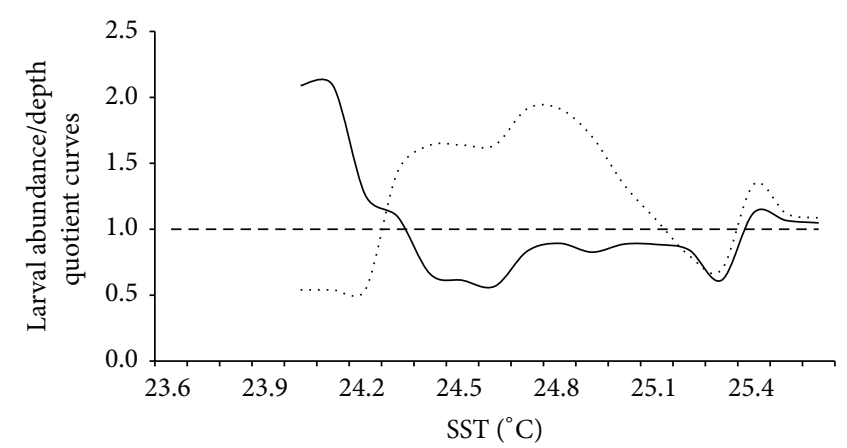

(a)

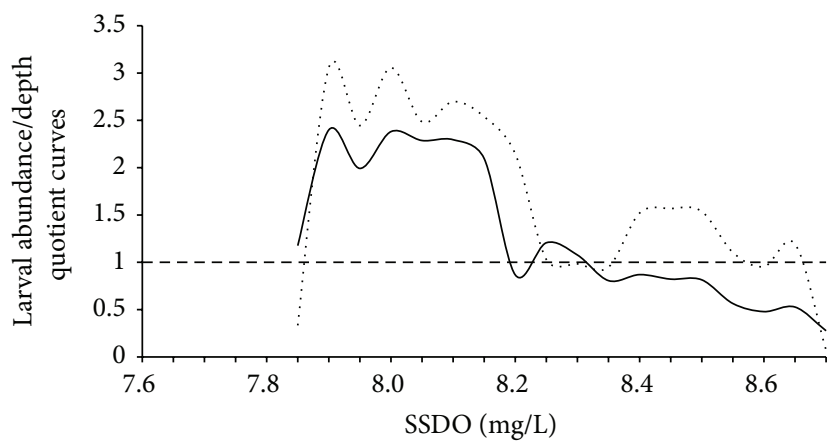

(c)

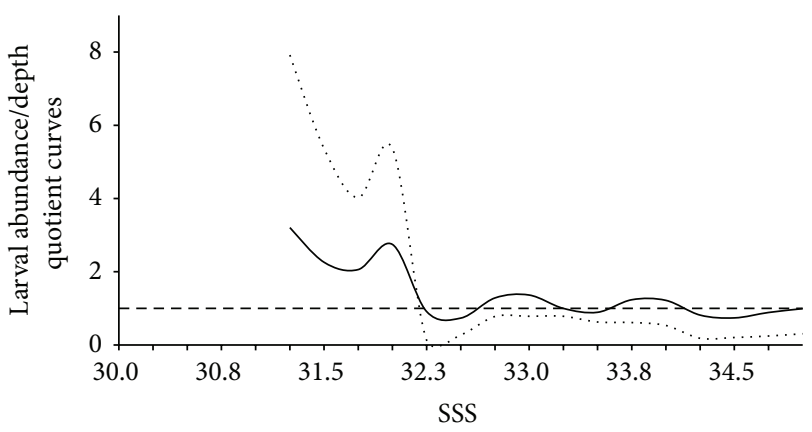

(b)

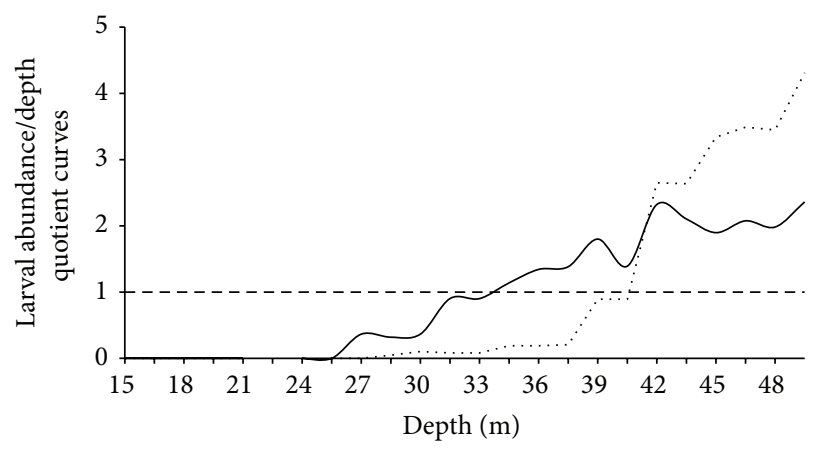

(d)

FIGURE 5: Quotient curves for anchovy, Engraulis encrasicolus (-), and round sardinella, Sardinella aurita (- - - - -), larval abundances with (a) temperature (SST, $\left.{ }^{\circ} \mathrm{C}\right),\left(\right.$ b) salinity (SSS), (c) dissolved oxygen (SSDO, $\mathrm{mg} \mathrm{L}^{-1}$ ), and (d) depth (m).

on the deep chlorophyll maximum layer probably owing to their inability to tolerate lower temperatures [7]. The extent of bathymetric differences could not be explained in the shallow Kavala Gulf where maximum depth does not exceed $50 \mathrm{~m}$.

It has been shown that the larval growth rates of anchovy and round sardinella are similar during the first month after hatching, estimated at 0.55 and $0.60 \mathrm{~mm} \mathrm{~d}^{-1}$, respectively [34]. The similar growth rate is the reason that predation pressure, one of the key parameters in larval abundance and distribution [35], upon the larvae of both species was assumed equal and thus was not considered in the present study.

The environmental requirements of anchovy and round sardinella larvae with respect to T, S, and DO did not differ significantly. Thus, these variables cannot explain the distribution pattern between their larvae. Similarly, the quotient analysis showed that, with the exception of temperature, the preferred range for the rest of environmental variables was similar for both species (Table 1, Figure 5). The preference of anchovy larvae for low salinity nutrient-rich coastal waters has been previously stated for NW Mediterranean [36], while Ettahiri et al. [37] report no relationship between water salinity and round sardinella spawning off the south Moroccan Atlantic coast but note that maximum round sardinella egg concentrations occur between 19 and $21.1^{\circ} \mathrm{C}$. Similarly, round sardinella's spawning has been associated with temperatures exceeding $20^{\circ} \mathrm{C}$ in Adriatic Sea [38].

Contrary to the general avoidance pattern, anchovy and round sardinella larvae were able to coexist in high numbers outside the southern boundary of Kavala Gulf (at stations 1417, Figure 2). In the summer, an anticyclonic eddy is formed outside the SW boundary of the gulf as a result of the northern Aegean water entering Kavala Gulf from the strait of Thassos, flowing westwards along the northern coast of Thassos island, and then incorporated into the (generally) cyclonic surface water circulation of the gulf [22]. A frontal structure associated with these patterns is formed at the SW part of the gulf, off the western coast of Thassos island (Figure 4). This area is rich in zooplankton [39] probably owing to this frontal structure [22,40]. The chances of larvae coexisting without any significant competition among them are higher in areas of high productivity resulting from continuous replenishment in nutrients, such as fronts and upwelling regions. Fronts have been previously reported to attract spawners [41] and, hence, to concentrate high numbers of larvae [42], while the general water circulation [43] and bottom topography [44] may also affect the general pattern of larval distributions. Finally, Olivar et al. [45] report that the larvae of anchovy and round sardinella are able to coexist under certain environmental conditions and that the likelihood of survival is greater when their concentrations coincide with high zooplankton biomass.

\section{Conflict of Interests}

The author declares that there is no conflict of interests regarding the publication of this paper. 


\section{Acknowledgments}

The present work is part of a research project (PENNED 2001) funded by the General Directorate of Research and Technology, Ministry of Development (Greece).

\section{References}

[1] C. J. Krebs, Ecology: The Experimental Analysis of Distribution and Abundance, HarperCollins College Publishers, New York, NY, USA, 1994.

[2] T. W. Schoener, "Resource partitioning in ecological communities," Science, vol. 185, no. 4145, pp. 27-39, 1974.

[3] P. Amarasekare, "Competitive coexistence in spatially structured environments: a synthesis," Ecology Letters, vol. 6, no. 12, pp. 1109-1122, 2003.

[4] P. A. Keddy, Competition, Chapman \& Hall, London, UK, 1989.

[5] A. Mougi and K. Nishimura, "Evolution of life-history traits collapses competitive coexistence," Journal of Theoretical Biology, vol. 248 , no. 3, pp. 552-559, 2007.

[6] G. Hardin, "The competitive exclusion principle," Science, vol. 131, no. 3409, pp. 1292-1297, 1960.

[7] A. Sabatés, M. P. Olivar, J. Salat, I. Palomera, and F. Alemany, "Physical and biological processes controlling the distribution of fish larvae in the NW Mediterranean," Progress in Oceanography, vol. 74, no. 2-3, pp. 355-376, 2007.

[8] A. C. Tsikliras, E. Antonopoulou, and K. I. Stergiou, "Spawning period of Mediterranean marine fishes," Reviews in Fish Biology and Fisheries, vol. 20, no. 4, pp. 499-538, 2010.

[9] I. Palomera and A. Sabatés, "Co-occurrence of Engraulis encrasicolus and Sardinella aurita eggs and larvae in the northwestern Mediterranean," Scientia Marina, vol. 54, pp. 61-67, 1990.

[10] Y. T. Wang and W. N. Tzeng, “Temporal succession and spatial segregation of clupeoid larvae in the coastal waters off the Tanshui River Estuary, northern Taiwan," Marine Biology, vol. 129, no. 1, pp. 23-32, 1997.

[11] P. Cetinić, A. Soldo, J. Dulčić, and A. Pallaoro, "Specific method of fishing for Sparidae species in the eastern Adriatic," Fisheries Research, vol. 55, no. 1-3, pp. 131-139, 2002.

[12] E. T. Koutrakis, "Temporal occurrence and size distribution of grey mullet juveniles (Pisces, Mugilidae) in the estuarine systems of the Strymonikos Gulf (Greece)," Journal of Applied Ichthyology, vol. 20, no. 1, pp. 76-78, 2004.

[13] P. Cury and A. Fontana, "Compétition et stratégies démographiques compares de deux espèces de sardinelles (Sardinella aurita et Sardinella maderensis) des cotes ouest-africaines," Aquatic Living Resources, vol. 1, pp. 165-180, 1988.

[14] FAO, The State of World Fisheries and Aquaculture, Food and Agricultural Organisation of the United Nations, Rome, Italy, 2000.

[15] A. C. Tsikliras, D. K. Moutopoulos, and K. I. Stergiou, "Reconstruction of Greek marine fisheries landings: national versus FAO statistics. In: Zeller D, Pauly D (eds) Reconstruction of marine fisheries catches for key countries and regions (19502005)," Fisher Centre Research Reports, vol. 15, no. 2, pp. 121-137, 2007.

[16] A. C. Tsikliras, M. Torre, and K. I. Stergiou, "Feeding habits and trophic level of round sardinella (Sardinella aurita) in the northeastern Mediterranean (Aegean Sea, Greece)," Journal of Biological Research, vol. 3, pp. 67-75, 2005.
[17] J. H. S. Blaxter and J. R. Hunter, "The biology of the clupeoid fishes," Advances in Marine Biology, vol. 20, no. C, pp. 1-223, 1982.

[18] G. Sinovčić, "Anchovy, Engraulis encrasicolus (Linnaeus, 1758): biology and fisheries case study," Acta Adriatica, vol. 41, pp. 353, 2000.

[19] A. C. Tsikliras and E. Antonopoulou, "Reproductive biology of round sardinella (Sardinella aurita) in the North-Eastern Mediterranean sea," Scientia Marina, vol. 70, no. 2, pp. 281-290, 2006.

[20] A. C. Tsikliras, "Climate-related geographic shift and sudden population increase of a small pelagic fish (Sardinella aurita) in the Eastern Mediterranean Sea," Marine Biology Research, vol. 4, no. 6, pp. 477-481, 2008.

[21] S. Somarakis, P. Drakopoulos, and V. Filippou, "Distribution and abundance of larval fish in the Northern Aegean SeaEastern Mediterranean-in relation to early summer oceanographic conditions," Journal of Plankton Research, vol. 24, no. 4, pp. 339-357, 2002.

[22] A. C. Tsikliras, E. T. Koutrakis, G. K. Sylaios, and A. A. Kallianiotis, "Summer distribution of fish larvae in Northern Aegean Sea," Journal of the Marine Biological Association of the United Kingdom, vol. 89, no. 6, pp. 1137-1146, 2009.

[23] A. Tsikliras and K. Stergiou, "Demersal-pelagic ratio in Greek fish landings (1964-2003)," Rapport du Commission International pour I'Exploration de la mer Méditerranée, vol. 38, p. 622, 2007.

[24] A. C. Tsikliras and E. T. Koutrakis, "Summer fish larval assemblages and station groups in the Northern Aegean Sea," Acta Adriatica, vol. 52, no. 1, pp. 57-66, 2011.

[25] R. H. Nonaka, Y. Matsuura, and K. Suzuki, "Seasonal variation in larval fish assemblages in relation to oceanographic conditions the Abrolhos Bank region off Eastern Brazil," Fishery Bulletin, vol. 98, no. 4, pp. 767-784, 2000.

[26] T. W. Schoener, "Nonsynchronous spatial overlap of lizards in patchy habitats," Ecology, vol. 51, pp. 408-418, 1970.

[27] N. M. Twatwa, C. D. van der Lingen, L. Drapeau, C. L. Moloney, and J. G. Field, "Characterising and comparing the spawning habitats of anchovy Engraulis encrasicolus and sardine Sardinops sagax in the Southern Benguela upwelling ecosystem," African Journal of Marine Science, vol. 27, no. 2, pp. 487-499, 2005.

[28] R. Schlitzer, Ocean Data View, 2014, http://odv.awi.de.

[29] E. T. Koutrakis, A. A. Kallianiotis, and A. C. Tsikliras, “Temporal patterns of larval fish distribution and abundance in a coastal area of Northern Greece," Scientia Marina, vol. 68, no. 4, pp. 585-595, 2004.

[30] G. Sylaios, A. Kallianiotis, and E. T. Koutrakis, "Anchovy larvae distribution in the North Aegean Sea in relation to the prevailing oceanographic conditions," in Proceedings of the 12th Hell Ichthyol Conference, pp. 136-139, 2005.

[31] G. Allain, P. Petitgas, and P. Lazure, "The influence of environment and spawning distribution on the survival of anchovy (Engraulis encrasicolus) larvae in the Bay of Biscay (NE Atlantic) investigated by biophysical simulations," Fisheries Oceanography, vol. 16, no. 6, pp. 506-514, 2007.

[32] I. Palomera, M. P. Olivar, J. Salat et al., "Small pelagic fish in the NW Mediterranean Sea: an ecological review," Progress in Oceanography, vol. 74, no. 2-3, pp. 377-396, 2007.

[33] E. Morote, M. P. Olivar, F. Villate, and I. Uriarte, "Diet of round sardinella, Sardinella aurita, larvae in relation to plankton 
availability in the NW Mediterranean," Journal of Plankton Research, vol. 30, no. 7, pp. 807-816, 2008.

[34] P. Walline, "Growth and ingestion rates of larval fish populations in the coastal waters of Israel," Journal of Plankton Research, vol. 9, no. 1, pp. 91-102, 1987.

[35] K. M. Bailey and E. D. Houde, "Predation on eggs and larvae of marine fishes and the recruitment problem," Advances in Marine Biology, vol. 25, pp. 1-83, 1989.

[36] J.-P. Bergeron, "Contrasting years in the Gironde estuary (Bay of Biscay, NE Atlantic) springtime outflow and consequences for zooplankton pyruvate kinase activity and the nutritional condition of anchovy larvae: an early view," ICES Journal of Marine Science, vol. 61, no. 6, pp. 928-932, 2004.

[37] O. Ettahiri, A. Berraho, G. Vidy, M. Ramdani, and T. D. Chi, "Observation on the spawning of Sardina and Sardinella off the South Moroccan Atlantic coast (21-26 N)," Fisheries Research, vol. 60, no. 2-3, pp. 207-222, 2003.

[38] S. Regner, "On the plankton stages of gilt sardine, Sardinella aurita Valenciennes, in the central Adriatic," Acta Adriatica, vol. 17, pp. 1-12, 1977.

[39] E. Michaloudi, A. Artemiou, and A. C. Tsikliras, "Mesozooplankton distribution in Kavala Gulf (summer 2003)," in Proceedings of the 8th Pan-Hellenic Symposium of Oceanography \& Fisheries, pp. 1-5, 2006.

[40] V. Kourafalou and K. Tsiaras, "A nested circulation model for the North Aegean Sea," Ocean Science, vol. 3, no. 1, pp. 1-16, 2007.

[41] F. H. Page, M. Sinclair, C. E. Naimie et al., "Cod and haddock spawning on Georges Bank in relation to water residence times," Fisheries Oceanography, vol. 8, no. 3, pp. 212-226, 1999.

[42] J. Le Fevre, "Aspects of the biology of frontal systems," Advances in Marine Biology, vol. 23, pp. 164-299, 1986.

[43] A. Cuttitta, V. Carini, B. Patti et al., "Anchovy egg and larval distribution in relation to biological and physical oceanography in the Strait of Sicily," Hydrobiologia, vol. 503, pp. 117-120, 2003.

[44] H. Fock and H.-C. John, "Fish larval patterns across the Reykjanes Ridge," Marine Biology Research, vol. 2, no. 3, pp. 191199, 2006.

[45] M.-P. Olivar, M. Emelianov, I. Uriarte et al., "Demographic structure of early stages of Engraulis encrasicolus and Sardinella aurita and water mass circulation in the southern," Rapport $d u$ Commission International pour I'Exploration de la mer Méditerranée, vol. 38, 2007. 

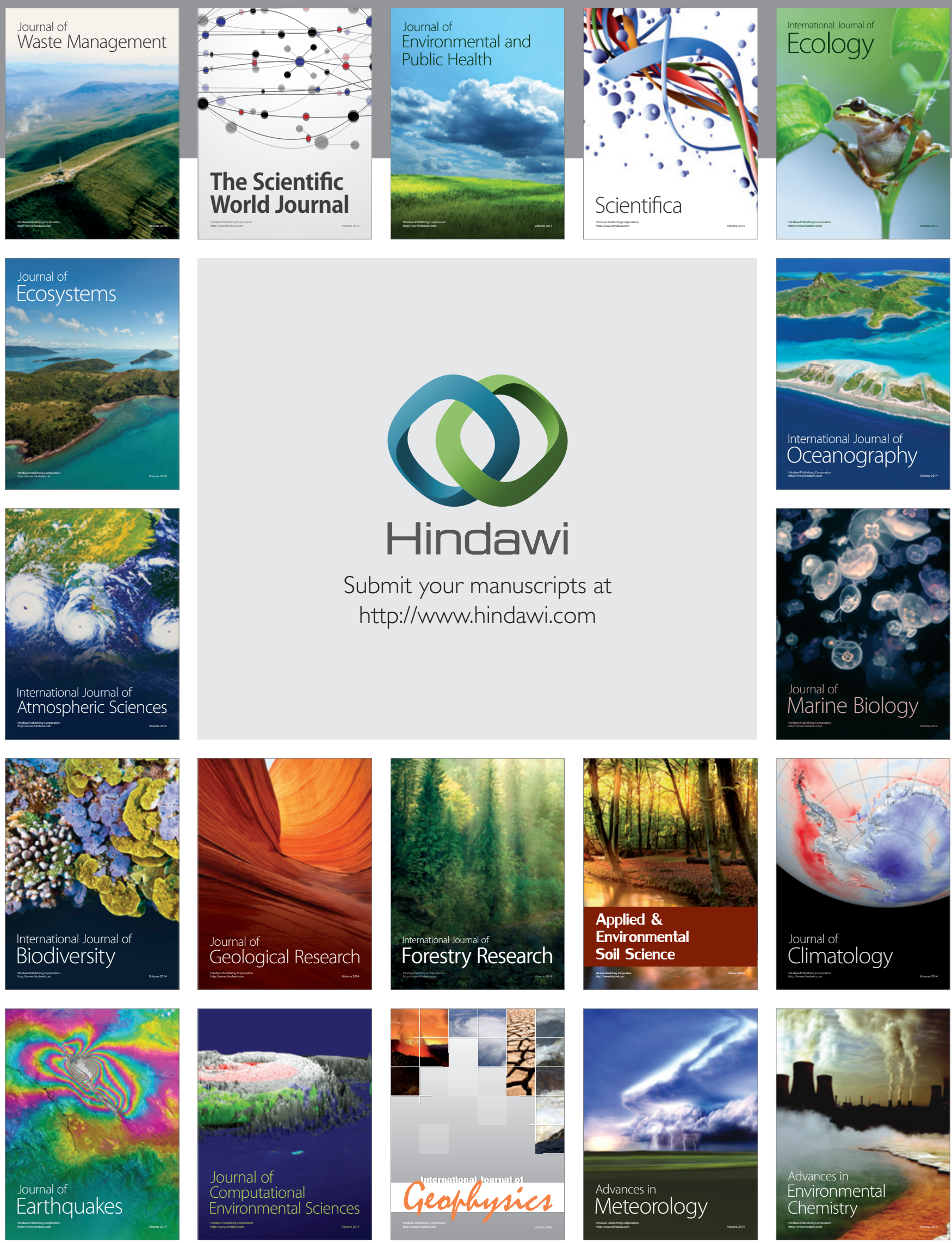